\title{
Screening of Microalgae for Biodiesel Feedstock
}

\author{
Xi Chen ${ }^{1,2}$, Guoqiang He1, Zhiping Deng1, Nan Wang2, Wei Jiang1, Sanfeng Chen ${ }^{*}$ \\ ${ }^{1}$ State Key Laboratory for Agrobiotechnology and College of Biological Sciences, China Agricultural University, \\ Beijing, China \\ ${ }^{2}$ Biotechnology Research Institute, Chinese Academy of Agricultural Sciences, Beijing, China \\ Email: ${ }^{*}$ chensf@cau.edu.cn
}

Received 31 March 2014; revised 30 April 2014; accepted 8 May 2014

Copyright (C) 2014 by authors and Scientific Research Publishing Inc.

This work is licensed under the Creative Commons Attribution International License (CC BY). http://creativecommons.org/licenses/by/4.0/

(c) (i) Open Access

\section{Abstract}

Three heterotrophic microalgae identified as Scenedesmus sp. Y5, Scenedesmus sp. Y7 and Chorellasp. Y9 were isolated and screened from natural water based on biomass yield and lipid productivity. Fatty acids' composition analysis showed that both Y5 and Y7 mainly contained C16:0, C18:1 $(n-9), C 18: 2(n-6)$ and C18:3 (n - 3) and Y9 mainly contained C16:0, C18:0 and C18:2 (n - 6), suggesting that these microalgae can be ideal feedstock for biodiesel. Considering the specific growth rate and lipid productivity, the culture conditions were optimized for Scenedesmus sp. Y5, Scenedesmus sp. Y7 and Chorellasp. Y9. Based on the optimization of cultural conditions, all of these three microalgae were tested in fed-batch fermentation, and their biomass productivities were $4.960 \mathrm{~g} \cdot \mathrm{L}^{-1} \cdot \mathrm{d}^{-1}, 5.907 \mathrm{~g} \cdot \mathrm{L}^{-1} \cdot \mathrm{d}^{-1}$ and $4.038 \mathrm{~g} \cdot \mathrm{L}^{-1} \cdot \mathrm{d}^{-1}$; lipid productivities reached 1.5120 $\mathrm{g} \cdot \mathrm{L}^{-1} \cdot \mathrm{d}^{-1}, 1.233 \mathrm{~g} \cdot \mathrm{L}^{-1} \cdot \mathrm{d}^{-1}$ and $0.8112 \mathrm{~g} \cdot \mathrm{L}^{-1} \cdot \mathrm{d}^{-1}$, respectively.

\section{Keywords}

Biodiesel, Scenedesmus, Chlorella, Fed-Batch Fermentation, Microalgal Lipid

\section{Introduction}

Fuels, representing nearly $70 \%$ of the total global energy requirements, are the most important conventional energy sources. Petroleum-based fuels, which are used mainly for transportation and energy sectors, are widely considered to be unsustainable energy source due to many serious problems, such as their depleting supplies and the contribution to accumulation of greenhouse gas (GHG) [1]. Biodiesel, referred as fatty acid methyl esters (FAMEs) and fatty acids ethyl esters (FAEEs), is recognized as an ideal substitute for diesel as it is made from

*Corresponding author. 
non-toxic, biodegradable and renewable resources and provides environmental benefits [2] [3]. Various renewable lipid sources such as vegetable oils, animal fats and waste oils have been chosen as the feedstock for biodiesel production, but currently seldom microalgae are chosen [1].

Actually microalgae are ideal feedstock for biodiesel and they are attracting worldwide attentions due to their excellent advantages comparing with other available renewable lipid sources. Except for the characteristics such as growing photosynthetically and assimilating $\mathrm{CO}_{2}$, microalgae have much higher growth rates and productivity, also can be cultured in outdoor ponds or indoor bioreactors, requiring much less land area than other conventional biodiesel feedstock of agricultural origin, such as canola, palm and corn [1] [4]-[6]. Moreover, microalgae can also grow heterotrophically in dark utilizing organic carbon sources which could eliminate the light requirement and reach high cell density in closed bioreactors [7]-[9]. It was important to choose suitable microalgae for biodiesel production. It was suggested that two factors, cell biomass and lipid content, were considered to be key indicators for the initial screen and assessment of microalgae species [10]. However, these two key factors can be replaced by lipid productivity, which is defined as lipid yield in the culture medium per unit volume per unit time [11]. Until now, many algal species have been selected for potential feedstock for mass biodiesel production, such as Chlorella species including C. vulgaris and C. protothecoides, marine Nannochloropsis and Tetreslmis, diatoms Cyclotella and so on [10] [12]-[14]. However, microalgaestrains used in algal industry remained very few currently.

In this study, three microalgae with higher lipid productivity were screened and isolated from rivers and lakes in China. Then the heterotrophic fermentation conditions of these species were optimized. Finally, the most lipid productivity was obtained by using fed-batch culture strategy. It was proved the possibility of utilizing these three microalgae as feedstock for biodiesel production.

\section{Methods}

\subsection{Collection, Isolation and Identification of Algal Strains}

Samples including microalgae were collected from the rivers and lakes of Beijing, Tianjin and Wuxi in China. The samples were stored in sterile plastic vials and sent to the laboratory as soon as possible for algal cell isolation.

The water was filtrated with filter papers to remove suspended particles and zooplankton, then added fresh Bsael medium. After a few days' culturing in the sun, the algae cell were collected by centrifugation (7000 g, 5 min, $4^{\circ} \mathrm{C}$ ); then transferred by loop and streaked onto agar plates [15]. After inoculation, all microalgae were cultured at $28^{\circ} \mathrm{C}$ for 10 - 14 days. The algal strains were identified according to their morphological characteristics [16].

A commercial available algal strains: 1067 (Chlorella sp.) purchased from FACHB-Collection (Wuhan, PRC) were used as reference strains. For morphological observation, cells from each strain were transferred into slides, and observed using a microscope (Olympus, Japan).

\subsection{Flask Culture of the Microalgae}

Strains cultivated under the same conditions were compared for the amounts of dry biomass, fatty acid profiles, and fatty acid content. Approximately $5 \mathrm{ml}$ algal cell suspension of each strain was inoculated in a $250 \mathrm{ml}$ flask with $100 \mathrm{~mL}$ Basel medium, and then statically cultivated at $26^{\circ} \mathrm{C}$ for 2 weeks. The contents of Basel medium are show as follows: glucose $10 \mathrm{~g} \cdot \mathrm{L}^{-1}, \mathrm{KNO}_{3} 1.25 \mathrm{~g} \cdot \mathrm{L}^{-1}, \mathrm{KH}_{2} \mathrm{PO}_{4} 1.25 \mathrm{~g} \cdot \mathrm{L}^{-1}, \mathrm{MgSO}_{4} \cdot 7 \mathrm{H}_{2} \mathrm{O} 1 \mathrm{~g} \cdot \mathrm{L}^{-1}$, Fe$\mathrm{SO}_{4} \cdot 7 \mathrm{H}_{2} \mathrm{O} 49.8 \mathrm{mg} \cdot \mathrm{L}^{-1}, \mathrm{CaCl}_{2} \cdot 2 \mathrm{H}_{2} \mathrm{O} 111 \mathrm{mg} \cdot \mathrm{L}^{-1}$, EDTA $500 \mathrm{mg} \cdot \mathrm{L}^{-1}, \mathrm{H}_{3} \mathrm{BO}_{3} 114.2 \mathrm{mg} \cdot \mathrm{L}^{-1}, \mathrm{MnCl}_{2} \cdot 4 \mathrm{H}_{2} \mathrm{O} 14.2$ $\mathrm{mg} \cdot \mathrm{L}^{-1}, \mathrm{MoO}_{3} 7.1 \mathrm{mg} \cdot \mathrm{L}^{-1}, \mathrm{CuSO}_{4} \cdot 5 \mathrm{H}_{2} \mathrm{O} 15.7 \mathrm{mg} \cdot \mathrm{L}^{-1}, \mathrm{Co}\left(\mathrm{NO}_{3}\right)_{2} \cdot 6 \mathrm{H}_{2} \mathrm{O} 4.9 \mathrm{mg} \cdot \mathrm{L}^{-1} \cdot \mathrm{pH}$ adjust to 6.1 .

\subsection{Lipid Extraction and Transesterification and Fatty Acid Analysis}

The cells were harvested by centrifugation $(8000 \times \mathrm{g}, 5 \mathrm{~min})$, rinsed with $5 \mathrm{~mL}$ deionized water, centrifuged again, and then lyophilized for lipid extraction and fatty acids analysis. Lipids of microalgae were extracted according to the method of Bligh and Dyer with a little improves [17]. For each sample, $100 \mathrm{mg}$ cells were weighed, mixed with $300 \mathrm{mg}$ quartz sand, adequately grounded in a mortar, then exhaustively extracted with 5 $\mathrm{mL}$ chloroform/methanol (2:1, v/v). Repeat extraction step twice to ensure that lipid is fully extracted, and then collected the organic phase by centrifugation $(5000 \times$ g, $5 \mathrm{~min}$ ). The collected liquid was added chloroform and 
water to give a final solvent ratio of chloroform: methanol: water of 1:1:0.9. The chloroform layer extracts was collected and dried by rotary evaporator $\left(40^{\circ} \mathrm{C}\right)$. Residual oil was stored in a freighter under $-20^{\circ} \mathrm{C}$ under nitrogen gas to prevent lipid oxidation or used directly for subsequent analysis.

\subsection{Analysis of Fatty Acid Composition}

Fatty acid methyl esters (FAMEs) were prepared by direct transmethylation using sodium methoxide (in methanol) as the catalyst according to the method by Rozés [18], then analyzed using a HP 6890 capillary gas chromatograph (Hewlett-Packard, Palo Alto, CA) equipped with a flame ionization detector (FID) at a temperature of $260^{\circ} \mathrm{C}$, a split/splitless injector and a HP-INNO wax capillary column $(30 \mathrm{~m} \times 0.32 \mathrm{~mm}$ ) (Agilent Technologies, Inc., Wilmington, DE). The carrier gas was high purity helium at $2.0 \mathrm{~mL} / \mathrm{min}$. The GC oven was initially held at $140^{\circ} \mathrm{C}$ for $5 \mathrm{~min}$; then the temperature was increased at $4^{\circ} \mathrm{C} / \mathrm{min}$ to $240^{\circ} \mathrm{C}$ and held isothermal for $15 \mathrm{~min}$. The detection limit of the chromatographic method was set to $0.01 \%$. Initial column temperature was set at $170^{\circ} \mathrm{C}$, which was subsequently raised to $230^{\circ} \mathrm{C}$ at $1^{\circ} \mathrm{C} / \mathrm{min}$. The injector was kept at $250^{\circ} \mathrm{C}$ with an injection volume of $2 \mu \mathrm{L}$ under splitless mode. The FID temperature was set at $270^{\circ} \mathrm{C}$. FAMEs identification was performed by comparison with standard certificate material (Sigma). The quantities of individual FAMEs were estimated from the peak areas on the chromatogram using heptadecanoic acid as the internal standard. Two replicates of each FAME analysis were done.

\subsection{DNA Analysis}

The genomic DNA of microalgae was extracted according to the manufacturer's instructions. 18S rRNA genes were amplified using the forward (5'CAGCAGCCGCGGTAATTC 3') and the reverse

(5'CATCTAAGGGCATCACAGACC 3') primers. PCR products were sequenced by the Life Technologies Corporation (China). Comparisons for similar sequences were carried out by BLAST Program (NCBI BLAST, USA).

\subsection{Culture Optimization for Y5, Y7 and Y9}

Y5, Y7 and Y9, the strains with the highest lipid production among our isolates, were chosen for optimization of growth conditions. All of the research in this section was performed using $250 \mathrm{~mL}$ flask containing $100 \mathrm{~mL}$ of various media shaken at $150 \mathrm{rpm}$, and inoculated with $5 \mathrm{~mL}$ algal cell suspension of each strain. The original media composition and other experimental conditions employed were described in the relevant results. Sampling was done every 1 - 2 days after inoculation. Two milliliters medium samples were collected from the culture and cell growth was measured by means of the absorbance of the suspension at $540 \mathrm{~nm}$ using a UV/Visible spectrophotometer (uv-2100, unic ${ }^{\mathrm{TM}} 7200$, USA) as Becker showed [19]. For optimal measurement, samples were diluted to appropriate concentration to keep the $\mathrm{OD}_{540}$ value between 0.2 and 0.8 .

\subsection{Fermentation Optimization in 5-L Bioreactor}

Fermentation of heterotrophic strains Y5, Y7 and Y9 was performed in a 5-L bioreactor (infors AG CH-4103, BIOTMINGEN, Switzerland). The components of heterotrophic medium [20] were as follows: $\mathrm{KH}_{2} \mathrm{PO}_{4} 0.7$ $\mathrm{g} \cdot \mathrm{L}^{-1}, \mathrm{~K}_{2} \mathrm{HPO}_{4} 0.3 \mathrm{~g} \cdot \mathrm{L}^{-1}, \mathrm{MgSO}_{4} \cdot 7 \mathrm{H}_{2} \mathrm{O} 0.3 \mathrm{~g} \cdot \mathrm{L}^{-1}, \mathrm{FeSO}_{4} \cdot 7 \mathrm{H}_{2} \mathrm{O} 3 \mathrm{mg} \cdot \mathrm{L}^{-1}$, glycine $0.1 \mathrm{~g} \cdot \mathrm{L}^{-1}$, vitamin $\mathrm{B}_{1} 0.01$ $\mathrm{mg} \cdot \mathrm{L}^{-1}, \mathrm{~A}_{5}$ trace mineral solution $1 \mathrm{ml} \cdot \mathrm{L}^{-1}$. Then $40 \mathrm{~g}$ glucose was added into $1 \mathrm{Lthe}$ medium. According to the substrate consuming rate, primary fed batch culture was performed in order to achieve optimal growth. Concentrated glucose solution was batch-fed to keep the concentration between 2 and $15 \mathrm{~g} \cdot \mathrm{L}^{-1}$; $\mathrm{pH}$ and temperature were well controlled automatically by computer at $6.0 \pm 0.1$ (or $9.0 \pm 0.1$ ) and $28^{\circ} \mathrm{C} \pm 0.5^{\circ} \mathrm{C}$, respectively. OD was controlled by coupling with stirring speed to keep it over $40 \%$ air saturation.

\subsection{Determination of Glucose Concentration, Dry Cell Weight and Specific Growth Rate}

The cells were centrifuged at $8000 \mathrm{~g}$ for $5 \mathrm{~min}$. Glucose concentrations in the supernatant were determined according to Miller [21]. The pellet was re-suspended in distilled water and filtered through a pre-dried what man GF/C filter paper (1.2 $\mu \mathrm{m}$ pore size). The algal cells on the filter paper discs were then lyophilized under vacuum condition until constant weight and were cooled down to room temperature in desiccators before weighted. The specific growth rate $(\mu)$ was calculated according to the equation, 


$$
\mu=\left(\ln X_{2}-\ln X_{1}\right) /\left(t_{2}-t_{1}\right)
$$

where $X_{2}$ and $X_{1}$ are the absorbance of the cell suspension at $540 \mathrm{~nm}$ at time $t_{2}$ and $t_{1}$, respectively.

\section{Results and Discussion}

\subsection{Isolation and Identification of Microalgae}

Seventeen strains of microalgae were isolated from the rivers and lakes of Beijing, Tianjin and Wuxi in China. Of the 17 strains, 11 grew well in heterotrophic condition. Comparisons of the biomass, lipid content and lipid productivity produced by the 11 heterotrophic strains and reference 1067 are shown in Table 1 . Strain Y3 produced the highest amount of cell biomass (14.5 g/L). Also, strains Y5, Y7 and Y9 produced higher amount of cell biomass than other strains except Y3, with $11.8 \mathrm{~g} / \mathrm{L}, 11.2 \mathrm{~g} / \mathrm{L}$ and $10.8 \mathrm{~g} / \mathrm{L}$ of cell biomass, respectively. Lipid content and lipid productivity of strains Y5, Y7 and Y9 are also higher than those of other strains. So the 3 strains were chosen for further identification, culture optimization and fermentation test. The 18S rRNA gene was PCR amplified from the genomic DNA of strains Y5, Y7 and Y9 and then sequenced. The phylogenetic analysis indicated that Y5 and Y7 have close relationship with Scenedesmus sp., and Y9 has close relationship with Chlorella species (Figure 1). Thus these three microalgae were named Scenedesmus sp. Y5, Scenedesmus sp.Y7 and Chlorella sp. Y9.

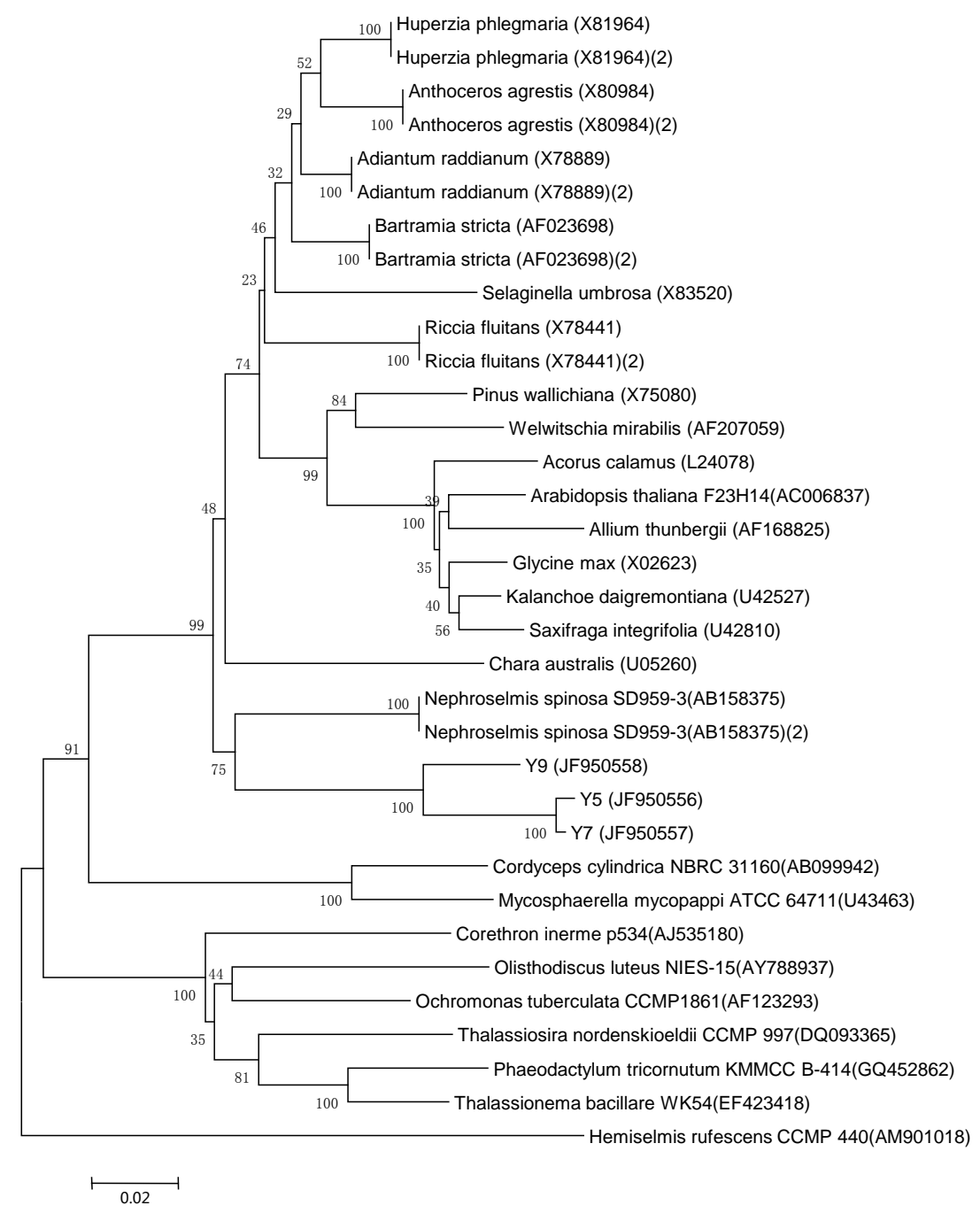

Figure 1. Phylogenetic tree of $18 \mathrm{~S}$ rDNA sequences of Y5, Y7, Y9 and reference algal strains. 
Table 1. The biomass, lipid content and lipid productivity of heterotrophic strains.

\begin{tabular}{cccccc}
\hline Algal strain & Collection site & Biomass concentration $\left(\mathrm{g} \cdot \mathrm{L}^{-1}\right)$ & Lipid quantity $(\mathrm{g})$ & Lipid content $(\%)$ & Lipid productivity $\left(\mathrm{g} \cdot \mathrm{L}^{-1} \cdot \mathrm{d}^{-1}\right)$ \\
\hline 1067 & & 8.8 & 1.4448 & 17.2 & 0.1445 \\
Y3 & Tai Lake, China & 14.5 & 1.6698 & 11.5 & 0.1670 \\
Y5 & Beijing, China & 11.8 & 4.484 & 30.8 & 0.484 \\
Y7 & Tai Lake, China & 11.2 & 2.2736 & 20.3 & 0.2274 \\
Y8 & Tai Lake, China & 8.4 & 0.6552 & 7.8 & 0.0655 \\
Y9 & Tai Lake, China & 10.8 & 1.8696 & 17.3 & 0.1870 \\
Y10 & Tai Lake, China & 8.3 & 0.6034 & 7.2 & 0.0603 \\
Y11 & Beijing, China & 6.0 & 0.636 & 10.6 & 0.0636 \\
Y14 & Beijing, China & 8.7 & 1.044 & 12 & 0.1044 \\
Y15 & Beijing, China & 3.5 & 0.343 & 9.8 & 0.0343 \\
Y16 & Beijing, China & 11.2 & 1.7584 & 15.7 & 0.1758 \\
Y17 & Tai Lake, China & 11.2 & 1.176 & 10.5 & 0.1176 \\
\hline
\end{tabular}

\subsection{Fatty Acid Profiles of Y5, Y7 and Y9}

Fatty acids synthesize by microalgal cell, the building blocks for various types of lipid, have chain lengths that range from C16 to C18 mainly, which are commonly feedstock for biodiesel [22]. Generally, most algae contain both saturated and mono-unsaturated fatty acids as their mainly components [23]. The properties of biodiesel made from microalgae are mainly influences by the fatty acid components [24] [25]. For example, biodiesel made from saturated fats shows superior oxidative stability and be with higher cetane number, while biodiesel from unsaturated fats, especially polyunsaturated, gives excellent cold-flow properties, but have low cetane numbers and poor oxidative stability, which is undesirable for a diesel fuel. Because the major fatty acids contained in algae is different according to the difference of algal species [5], it is necessary to examine the suitability of its fatty acid composition in the selection of microalgae as a feedstock for biodiesel production.

The fatty acid compositions of the 3 selected Scenedesmus sp.Y5, Scenedesmus sp. Y7 and Chlorella sp. Y9 cultured in Basal medium with glucose as carbon source were investigated (Table 2). It was found that C16:0, C18:1 ( $n-9)$, C18:2 $(n-6)$ and C18:3 $(n-3)$ were the major fatty acids for Scenedesmus sp. Y5 and Y7, which accounted for $90.41 \%$ and $93.21 \%$ of the total fatty acids (TFAs). While C16:0, C18:0 and C18:2 (n-6) were the major fatty acids for Chlorella sp. Y9, which accounted for more than $89.94 \%$ of the total fatty acids (TFAs). The proportion of oleic acid (C18:1 $(n-9)$ ) in the total fatty acids is $24.72 \%$, which has been considered to improve low-temperature stability with maintaining the cetane number at an ideal level [24]. Although percentage of polyunsaturated fatty acids total fatty acids, especially C18:2 $(n-6)$ was very high, and it could reduced the oxidative stability, if appropriate methods of improving property of biodiesel made from microalgae are conducted, such as adding antioxidants to lengthen oxidative stability, biodiesel from microalgae can be implemented for jet fuel due to the better fuel properties of petroleum diesel [26]. So from the point of view from the fatty acid profiles, Scenedesmus sp. Y5, Scenedesmus sp. Y7 and Chlorella sp. Y9 can be ideal feed stocks for biodiesel.

\subsection{Culture Optimization for Strains Y5, Y7 and Y9}

In order to increase lipid productivity of Scenedesmus sp. Y5, Scenedesmus sp. Y7 and Chlorella sp. Y9, the following study was conducted.

\subsubsection{Optimization of Initial Carbon Sources}

Four carbon sources (fructose, glucose, sucrose, galactose and lactose) were investigated about their influence on the heterotrophic growth of strains $\mathrm{Y} 5, \mathrm{Y} 7$ and $\mathrm{Y} 9$ in flasks under the same nitrogen concentration $\left(\mathrm{KNO}_{3}\right.$, 
Table 2. Fatty acid profiles of Scenedesmus sp. Y5, Scenedesmus sp. Y7 and Chlorella sp. Y9 cultured in Basal medium with glucose as carbon source.

\begin{tabular}{|c|c|c|c|}
\hline \multirow{2}{*}{ Fatty acids } & \multicolumn{3}{|c|}{ Content (\%) } \\
\hline & Scenedesmus sp. Y5 & Scenedesmus sp. Y7 & Chlorella sp. Y9 \\
\hline C12:0 & 0.04 & NA & 1.47 \\
\hline C14:0 & 0.21 & NA & 0.46 \\
\hline C14:1 & 0.01 & NA & 0.43 \\
\hline C16:0 & 23.17 & 26.64 & 29.93 \\
\hline C16:1 & 0.45 & 0.5 & 0.21 \\
\hline C18:0 & 1.61 & NA & 14.86 \\
\hline C18:1 & NA & 1.16 & NA \\
\hline t11-C18:1 & 0.31 & 0.10 & NA \\
\hline C18:1 (n-9) & 28.15 & 24.72 & 3.53 \\
\hline C18:1 (n-7) & 1.80 & 1.92 & 0.21 \\
\hline C18:2 (n-6) & 25.91 & 31.27 & 45.15 \\
\hline C18:3 (n-6) & 0.38 & 0.71 & NA \\
\hline C18:3 $(n-3)$ & 13.18 & 10.58 & 1.96 \\
\hline C20:0 & 0.10 & 0.09 & 0.39 \\
\hline C20:1 & 0.26 & 0.49 & 0.23 \\
\hline C22:0 & 0.04 & 0.57 & 0.1 \\
\hline $\mathrm{C} 22: 4(\mathrm{n}-6)$ & NA & 0.12 & NA \\
\hline C22:5 $(n-3)$ & 0.89 & 0.92 & NA \\
\hline $\mathrm{C} 24: 0$ & 0.22 & 0.23 & 0.44 \\
\hline others & 3.27 & 0.98 & 0.63 \\
\hline Mounsatd $^{\mathrm{a}}$ & 30.98 & 28.89 & 4.61 \\
\hline Pounsatd $^{\mathrm{b}}$ & 40.36 & 43.60 & 47.11 \\
\hline Unsatd $^{\mathrm{c}}$ & 71.34 & 72.49 & 51.72 \\
\hline DUS $(\Delta / \mathrm{mol})^{\mathrm{d}}$ & 1.28 & 1.30 & 1.01 \\
\hline
\end{tabular}

${ }^{\mathrm{a}}$ Mounsatd: percentage of monounsaturated fatty acids (\% of total fatty acids). ${ }^{\mathrm{b}}$ Pounsatd: percentage of polyunsaturated fatty acids (\% of total fatty acids). ${ }^{~}$ Unsatd: percentage of unsaturated fatty acids (\% of total fatty acids). ${ }^{\mathrm{d}} \mathrm{DUS}$ ( $\left.\mathrm{r} / \mathrm{mol}\right)$ : degree of fatty acid unsaturation $=[1.0(\%$ monoenes $)+2.0(\%$ dienes $)+3.0(\%$ trienes $)+4.0(\%$ tetraenes $)] / 100$.

$1.25 \mathrm{~g} \cdot \mathrm{L}^{-1}$ ). The Figure 2(a) showed that, within 7 days, adding glucose as carbon source for strains $\mathrm{Y} 5$, $\mathrm{Y} 7$ and Y9 gave the best result. Under this condition, the specific growth rate of strains Y5, Y7 and Y9 reached $0.41 \mathrm{~d}^{-1}$, $0.50 \mathrm{~d}^{-1}$ and $0.47 \mathrm{~d}^{-1}$, respectively. The lipid productivity of all of them reached $0.22 \mathrm{~g} \cdot \mathrm{L}^{-1} \cdot \mathrm{d}^{-1}, 0.09 \mathrm{~g} \cdot \mathrm{L}^{-1} \cdot \mathrm{d}^{-1}$ and $0.16 \mathrm{~g} \cdot \mathrm{L}^{-1} \cdot \mathrm{d}^{-1}$, respectively.

\subsubsection{Optimization of Initial Nitrogen Sources}

Four nitrogen sources (urea, potassium nitrate, yeast extract, ammonium sulfate and ammonium chloride) were investigated about their influence on algal heterotrophic growth in flasks under the same glucose concentration $\left(20 \mathrm{~g} \cdot \mathrm{L}^{-1}\right)$. Figure 2(b) showed that, yeast extract (YE), potassium nitrate (PN) and urea (UR) provided good nitrogen for strains Y5, Y7 and Y9. Using yeast extract as nitrogen sources, the specific growth rate and li- 


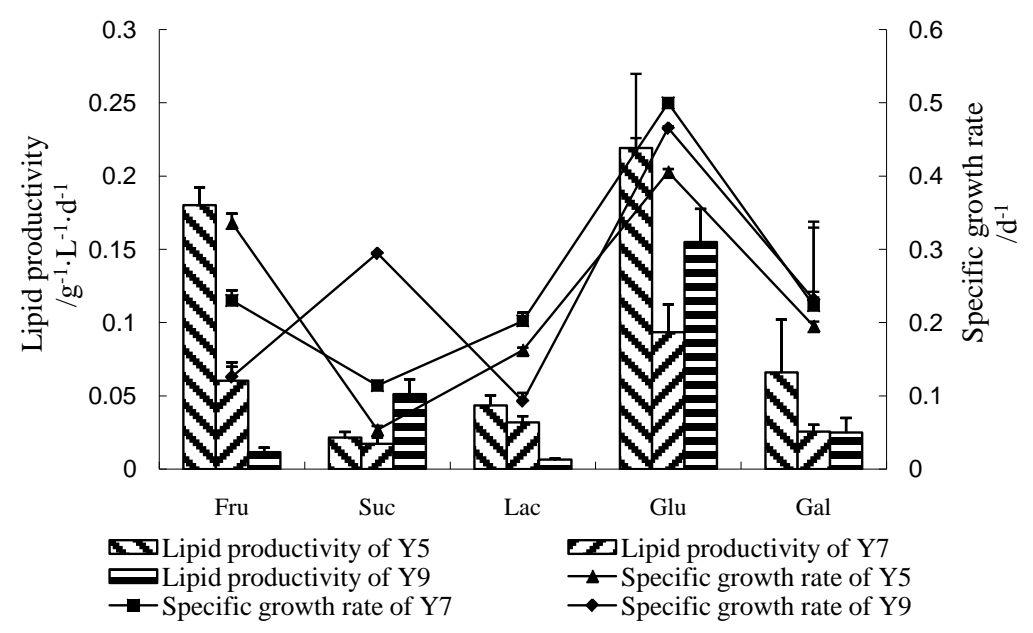

(a)

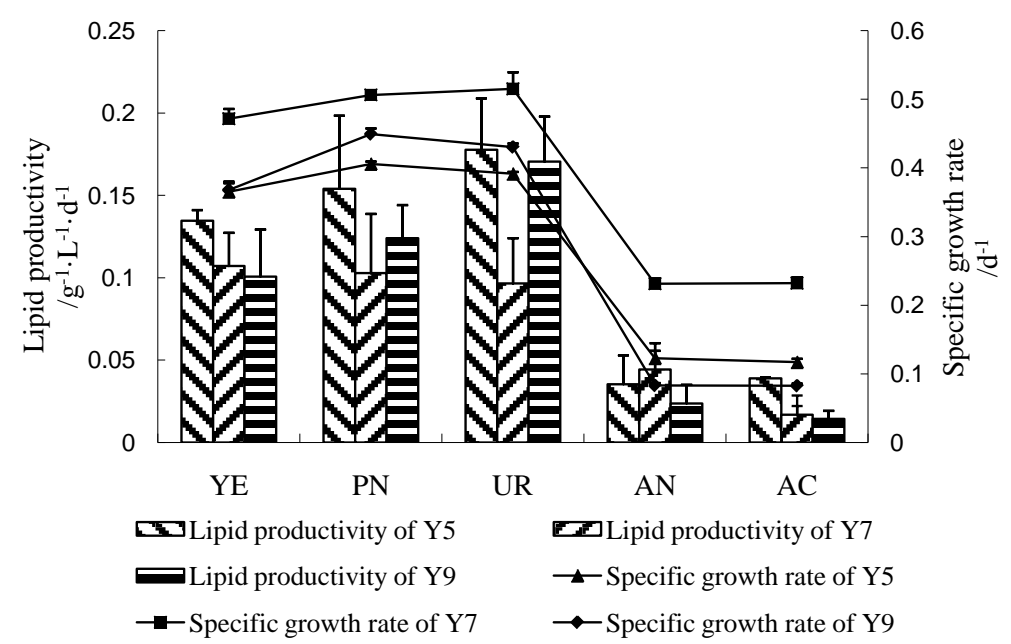

(b)

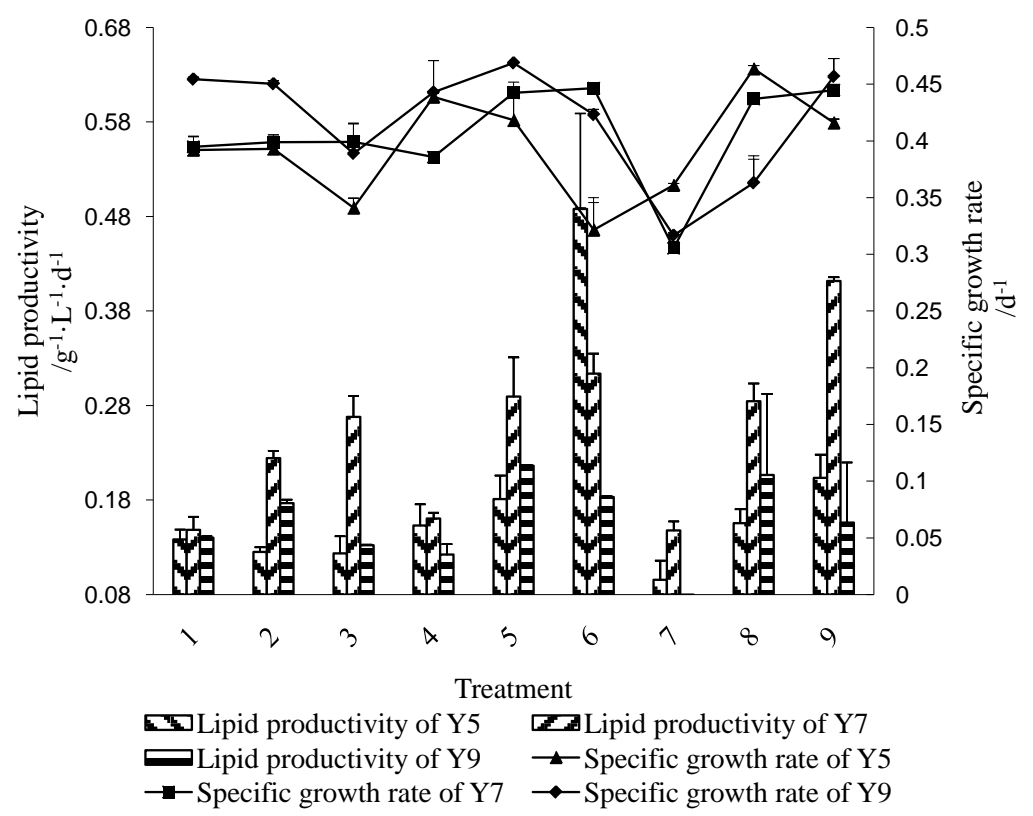

(c) 


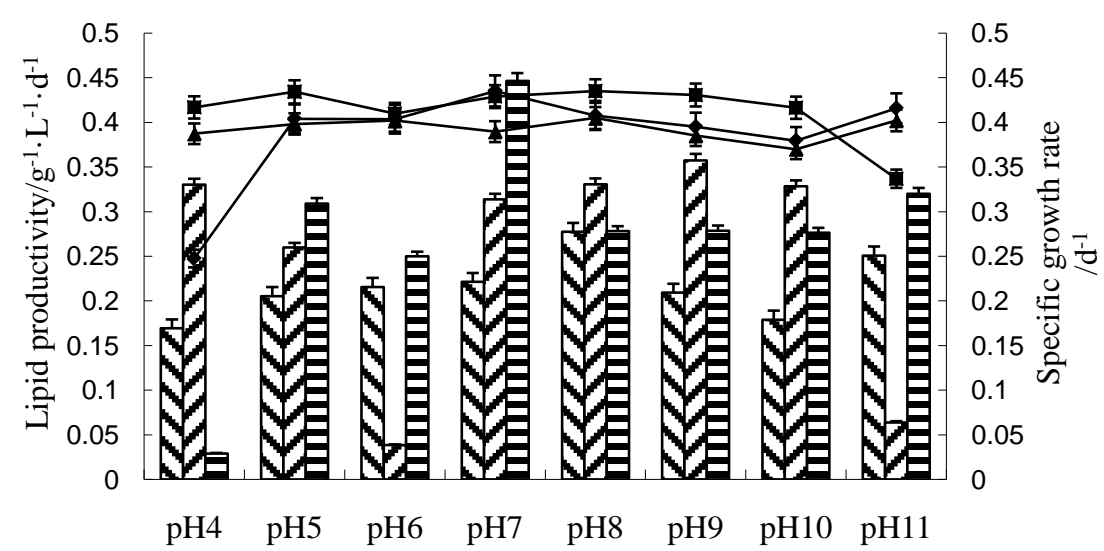

$\$$ Lipid productivity of Y5 2 Lipid productivity of Y7

$\longrightarrow$ Lipid productivity of Y9 $\rightarrow$ Specific growth rate of $\mathrm{Y5}$

$\rightarrow$ Specific growth rate of $\mathrm{Y} 7 \rightarrow$ Specific growth rate of $\mathrm{Y9}$

(d)

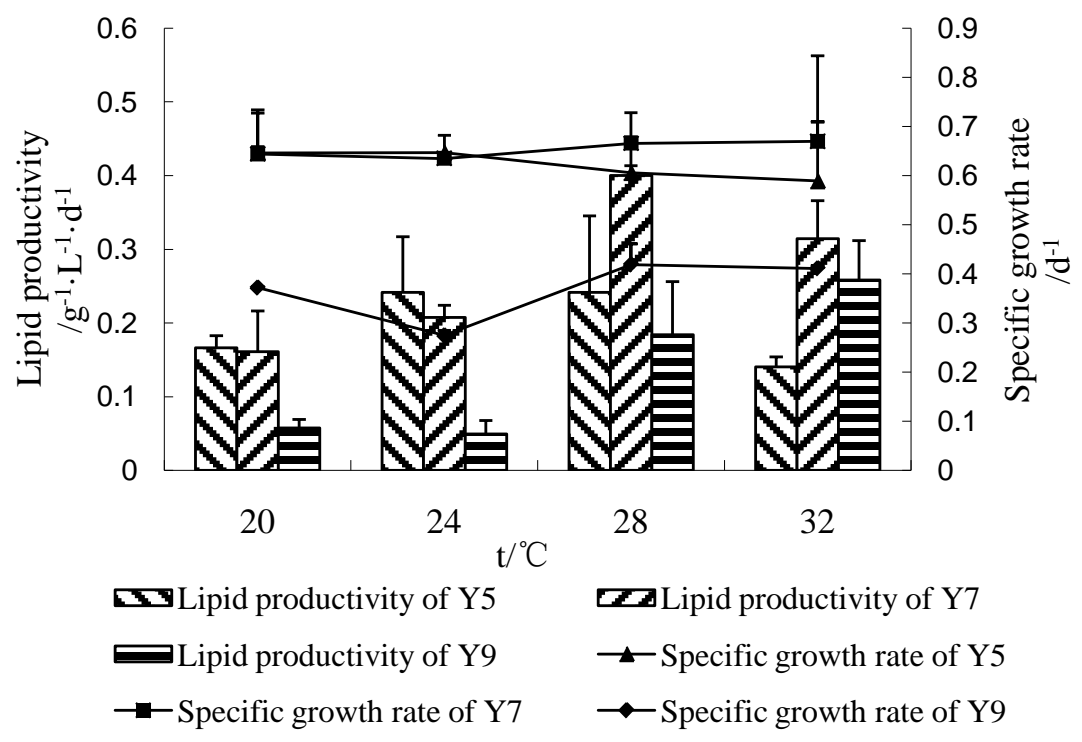

(e)

Figure 2. (a) Specific growth rate, lipid productivity of Scenedesmus sp. Y5, Scenedesmus sp. Y7 and Chlorella sp. Y9 in batch culture with $20 \mathrm{~g} \cdot \mathrm{L}^{-1}$ of various sugars. Fru, fructose; Suc, sucrose; Lac, lactose; Glu, glucose; Gal, galactose; (b) Specific growth rate, lipid productivity of Scenedesmus sp. Y5, Scenedesmus sp. Y7 and Chlorella sp. Y9 in batch culture with $1.25 \mathrm{~g} \cdot \mathrm{L}^{-1}$ of various nitrogen sources. YE, yeast extract; PN, potassium nitrate; UR, urea; AN, ammonium nitrate; AC, ammonium chloride; (c) Specific growth rate, lipid productivity of Scenedesmus sp. Y5, Scenedesmus sp. Y7 and Chlorella sp. Y9 in batch culture with different combinations of carbon and nitrogen. 1: Glucose $20 \mathrm{~g} \cdot \mathrm{L}^{-1}$, Urea $0.3 \mathrm{~g} \cdot \mathrm{L}^{-1} ; 2$ : Glucose 20 $\mathrm{g} \cdot \mathrm{L}^{-1}$, Urea $1.2 \mathrm{~g} \cdot \mathrm{L}^{-1}$; 3 : Glucose $20 \mathrm{~g} \cdot \mathrm{L}^{-1}$, Urea $2.1 \mathrm{~g} \cdot \mathrm{L}^{-1} ; 4$ : Glucose $30 \mathrm{~g} \cdot \mathrm{L}^{-1}$, Urea $0.3 \mathrm{~g} \cdot \mathrm{L}^{-1}$; 5 : Glucose $30 \mathrm{~g} \cdot \mathrm{L}^{-1}$, Urea $1.2 \mathrm{~g} \cdot \mathrm{L}^{-1} ; 6$ : Glucose $30 \mathrm{~g} \cdot \mathrm{L}^{-1}$, Urea 2.1 $\mathrm{g} \cdot \mathrm{L}^{-1}$; 7: Glucose $40 \mathrm{~g} \cdot \mathrm{L}^{-1}$, Urea $0.3 \mathrm{~g} \cdot \mathrm{L}^{-1}$; 8: Glucose $40 \mathrm{~g} \cdot \mathrm{L}^{-1}$, Urea $1.2 \mathrm{~g} \cdot \mathrm{L}^{-1} ; 9$ : Glucose $40 \mathrm{~g} \cdot \mathrm{L}^{-1}$, Urea $2.1 \mathrm{~g} \cdot \mathrm{L}^{-1}$. (When it comes to C. reinhardii Y7, YE was used as nitrogen source.); (d) Specific growth rate, lipid productivity of Scenedesmus sp. Y5, Scenedesmus sp. Y7 and Chlorella sp. Y9 in batch culture under different pH conditions; (e) Specific growth rate, lipid productivity of Scenedesmus sp. Y5, Scenedesmus sp. Y7 and Chlorella sp. Y9 in batch culture under different temperature conditions. 
pid productivity of them reached $0.365 \mathrm{~d}^{-1}, 0.472 \mathrm{~d}^{-1}, 0.368 \mathrm{~d}^{-1}$ and $0.135 \mathrm{~g} \cdot \mathrm{L}^{-1} \cdot \mathrm{d}^{-1}, 0.107 \mathrm{~g} \cdot \mathrm{L}^{-1} \cdot \mathrm{d}^{-1}, 0.101$ $\mathrm{g} \cdot \mathrm{L}^{-1} \cdot \mathrm{d}^{-1}$; the specific growth rate and lipid productivity of strains $\mathrm{Y} 5, \mathrm{Y} 7$ and $\mathrm{Y} 9$ was $0.406 \mathrm{~d}^{-1}, 0.506 \mathrm{~d}^{-1}$, $0.449 \mathrm{~d}^{-1}$ and $0.154 \mathrm{~g} \cdot \mathrm{L}^{-1} \cdot \mathrm{d}^{-1}, 0.103 \mathrm{~g} \cdot \mathrm{L}^{-1} \cdot \mathrm{d}^{-1}, 0.124 \mathrm{~g} \cdot \mathrm{L}^{-1} \cdot \mathrm{d}^{-1}$ with potassium nitrate as nitrogen source; when adding urea in medium, the specific growth rate and lipid productivity of Y5, Y7 and Y9 reached $0.391 \mathrm{~d}^{-1}$, $0.515 \mathrm{~d}^{-1}, 0.430 \mathrm{~d}^{-1}$ and $0.178 \mathrm{~g} \cdot \mathrm{L}^{-1} \cdot \mathrm{d}^{-1}, 0.096 \mathrm{~g} \cdot \mathrm{L}^{-1} \cdot \mathrm{d}^{-1}, 0.170 \mathrm{~g} \cdot \mathrm{L}^{-1} \cdot \mathrm{d}^{-1}$, respectively.

\subsubsection{Optimization of Carbon and Nitrogen Source Combinations}

The $\mathrm{C} / \mathrm{N}$ ratio not only affected on the lipid content but also affected on the fatty acid composition of Chlorella sorokiniana in heterotrophic batch culture. It was found that low $\mathrm{C} / \mathrm{N}$ ratios favored a high proportion of trienoic fatty acids at the expense of monoenoic acids [27]. The Figure 2(c) showed that, for Y5, the best combination of carbon and nitrogen source for the specific growth rate was glucose $40 \mathrm{~g} \cdot \mathrm{L}^{-1}$ and urea $2.1 \mathrm{~g} \cdot \mathrm{L}^{-1}$. The specific growth rate of Y5 reached $0.463 \mathrm{~d}^{-1}$ in this condition. However, the lipid productivity reached the highest level $\left(0.488 \mathrm{~g} \cdot \mathrm{L}^{-1} \cdot \mathrm{d}^{-1}\right)$ when adding glucose $30 \mathrm{~g} \cdot \mathrm{L}^{-1}$ and urea $2.1 \mathrm{~g} \cdot \mathrm{L}^{-1}$ in the medium. It was showed that the optimal composition of carbon and nitrogen source of $\mathrm{Y} 7$ for the specific growth rate was glucose $30 \mathrm{~g} \cdot \mathrm{L}^{-1}$ and yeast extract $7.84 \mathrm{~g} \cdot \mathrm{L}^{-1}\left(0.447 \mathrm{~d}^{-1}\right)$ and for the lipid productivity was glucose $40 \mathrm{~g} \cdot \mathrm{L}^{-1}$ and yeast extract $7.84 \mathrm{~g} \cdot \mathrm{L}^{-1}$ $\left(0.412 \mathrm{~g} \cdot \mathrm{L}^{-1} \cdot \mathrm{d}^{-1}\right)$. For Chlorella sp. Y9, when using $30 \mathrm{~g} \cdot \mathrm{L}^{-1}$ and urea $2.1 \mathrm{~g} \cdot \mathrm{L}^{-1}$, both the specific growth rate and the lipid productivity reached $0.496 \mathrm{~d}^{-1}$ and $0.216 \mathrm{~g} \cdot \mathrm{L}^{-1} \cdot \mathrm{d}^{-1}$, respectively. This composition of carbon and nitrogen source was optimal for Y9.

\subsubsection{Optimization of Initial $\mathrm{pH}$}

Because $\mathrm{pH}$ condition impacts many aspects of media biochemistry, maintenance of a suitable $\mathrm{pH}$ range throughout culturing was of importance. The $\mathrm{pH}$ of culture medium may not only affect on the utility efficiency of organic carbon by microalgae, but also it will affect the medium absorption and utilization of ions by algae cells and re-use and toxicity of the metabolites [23]. As shown in Figure 2(d), there was no significant difference for the specific growth rate in different $\mathrm{pH}$ conditions for all of the three microalgae. However, using the lipid productivity as indicator, $\mathrm{pH}$ 8, 9 and 7 was optimal for Y5, Y7 and Y9, respectively.

\subsubsection{Optimization of Initial Temperature}

As shown in Figure 2(e), given priority to lipid productivity index, the suitable temperature for three microalgae $\mathrm{Y} 5, \mathrm{Y} 7$ and $\mathrm{Y} 9$ was $28^{\circ} \mathrm{C}, 28^{\circ} \mathrm{C}$ and $32^{\circ} \mathrm{C}$. At $28^{\circ} \mathrm{C}$, the specific growth rate and lipid productivity of $\mathrm{Y} 5$ were $0.61 \mathrm{~d}^{-1}$, and $0.24 \mathrm{~g} \cdot \mathrm{L}^{-1} \cdot \mathrm{d}^{-1}$, respectively. For $\mathrm{Y} 7$, the specific growth rate and lipid productivity reached 0.67 $\mathrm{d}^{-1}$, and $0.40 \mathrm{~g} \cdot \mathrm{L}^{-1} \cdot \mathrm{d}^{-1}$, respectively, at $28^{\circ} \mathrm{C}$. At $32^{\circ} \mathrm{C}$, the specific growth rate and lipid productivity of $\mathrm{Y} 9$ was $0.41 \mathrm{~d}^{-1}$ and $0.26 \mathrm{~g} \cdot \mathrm{L}^{-1} \cdot \mathrm{d}^{-1}$. According to these data, the following fermentation experiments were operated at $28^{\circ} \mathrm{C}$.

\subsection{Fed-Batch Fermentation for Lipid Production}

Fed-batch cultivation mode is widely used in fermentation, which can extend the exponential growth phase of cells, and increase the biomass production and accumulation of metabolites. In this experiment, glucose was added when the glucose concentration in the medium was below $10 \mathrm{~g} \cdot \mathrm{L}^{-1}$ in order to obtain the maximum yield of biomass. As show in Figures 3-5, the dry biomass of Y5, Y7 and Y9 reached the stationary phase after fermentation $81.5 \mathrm{~h}, 84 \mathrm{~h}$ and $81.5 \mathrm{~h}$. At that time, the dry biomass of $\mathrm{Y} 5\left(24.2 \mathrm{~g} \cdot \mathrm{L}^{-1}\right)$, of $\mathrm{Y} 7\left(22.88 \mathrm{~g} \cdot \mathrm{L}^{-1}\right)$ and of Y9 $\left(19.62 \mathrm{~g} \cdot \mathrm{L}^{-1}\right)$ was obtained.

By using fed-batch fermentation, the high dry cell biomass productivity for Y5, Y7 and Y9 reached 4.96 $\mathrm{g} \cdot \mathrm{L}^{-1} \cdot \mathrm{d}^{-1}, 5.907 \mathrm{~g} \cdot \mathrm{L}^{-1} \cdot \mathrm{d}^{-1}$ and $4.038 \mathrm{~g} \cdot \mathrm{L}^{-1} \cdot \mathrm{d}^{-1}$, respectively, which were about $2.21,1.98$ and 2.45 -fold of those obtained by flask culture. Based on these results, cells of Y5, Y7 and Y9 were harvested after the end of fermentation, then determined cell lipid content, and lipid productivity was calculated $1.512 \mathrm{~g} \cdot \mathrm{L}^{-1} \cdot \mathrm{d}^{-1} 1.233$ $\mathrm{g} \cdot \mathrm{L}^{-1} \cdot \mathrm{d}^{-1}$ and $0.8112 \mathrm{~g} \cdot \mathrm{L}^{-1} \cdot \mathrm{d}^{-1}$, respectively, which were about 7.42, 2.99 and 3.93-fold of those obtained by flask culture. These results are consistent with the findings that when the fed-batch fermentation was taken, $C$. zofingiensis could accumulate lipids up to $20.7 \mathrm{~g} \cdot \mathrm{L}^{-1}$, and lipid productivity reached $1.38 \mathrm{~g} \cdot \mathrm{L}^{-1} \cdot \mathrm{d}^{-1}[10]$.

In addition to several microalgae which have been widely studied, many new microalgae including Haematococcuspluvialis, Chlamydomonasreinhardtii, Neochlorisoleabundans, Botryococcusbrauniil, S. obliquus, C. minutissima and so on, were reported to have the potential using as biodiesel feedstock recently [3] [28]-[33]. 


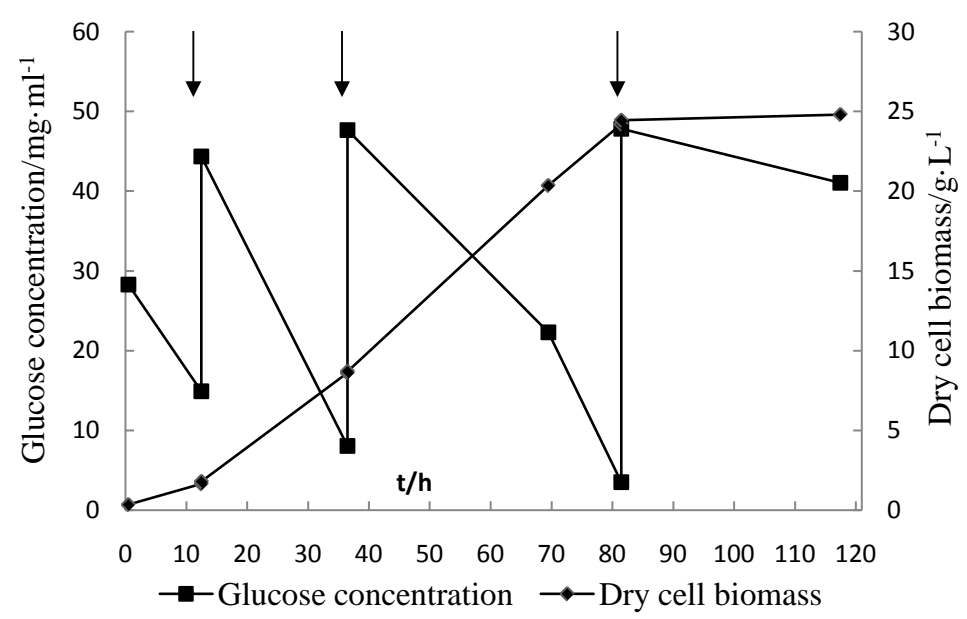

Figure 3. The cell growth and glucose consumption curve of Scenedesmus sp. Y5 and feeding of substrate. Arrows indicates adding the glucose.

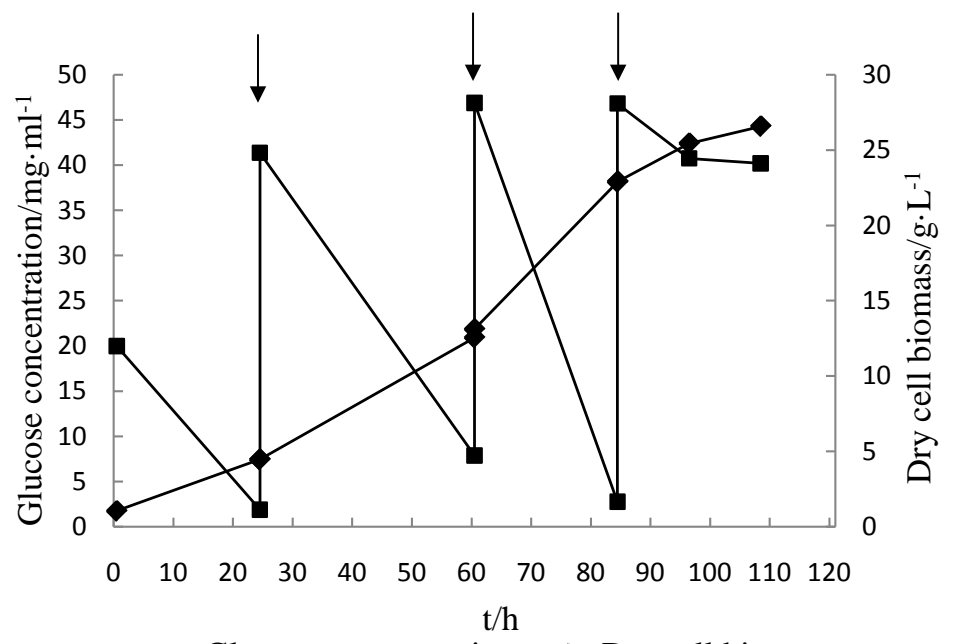

$\rightarrow$ Glucose concentration $\neg$-Dry cell biomass

Figure 4. The cell growth and glucose consumption curve of Scenedesmus sp. Y7 and feeding of substrate. Arrows indicates adding the glucose.

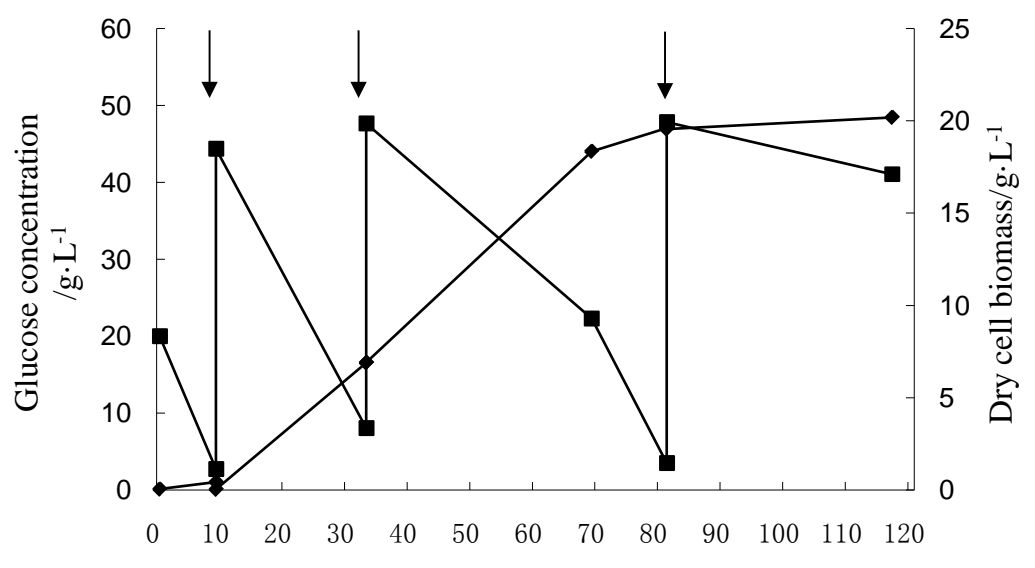

$\rightarrow$-Glucose concentration $\rightarrow$-Dry cell biomass

Figure 5. The cell growth and glucose consumption curve of Chlorella sp. Y9 and feeding of substrate. Arrows indicates adding the glucose. 
Furthermore, compared with other microbial organisms used in the production of biofuel, microalgae can not only accumulate high level lipid productivity for biodiesel production, but also produce other form of energy such as biohydrogen, hydrocarbon and so on. Besides, microalgae can also produce many other useful materials such as carotenoide, lutein, astaxanthin, EPA, DHA and so on. These productions all have biological activity and are very expensive. Recently, many studies have focused on the use of microalgae for sewage treatment, fixation of carbon dioxide of power plant emissions, as a cell factory to produce active substances, which will provides some auxiliary supports in the engineering and technical process of algal biodiesel production, and further will cut costs down.

\section{Conclusion}

Three microalgae Scenedesmus sp. Y5, Scenedesmus sp. Y7and Chlorella sp. Y9 were isolated and screened based on the indicators including biomass concentration, fatty acid profiles, and specific growth rate and lipid productivity. Based on the optimization of cultural conditions, Y5, Y7 and Y9 were tested in fed-batch fermentation for lipid production, and their lipid productivities reached $1.512 \mathrm{~g} \cdot \mathrm{L}^{-1} \cdot \mathrm{d}^{-1} 1.233 \mathrm{~g} \cdot \mathrm{L}^{-1} \cdot \mathrm{d}^{-1}$ and 0.8112 $\mathrm{g} \cdot \mathrm{L}^{-1} \cdot \mathrm{d}^{-1}$, which were about 7.42, 2.99 and 3.93-fold of those obtained by flask culture. Scenedesmus sp. Y5, Scenedesmus sp.Y7 and Chlorella sp. Y9 were proved to have the potential for biodiesel production by genetic modification and conditions optimizing.

\section{Acknowledgements}

This work was supported by National High Technology Research and Development Program of China (No. 2013AA065802).

\section{References}

[1] Chisti, Y. (2007) Biodiesel from Microalgae. Biotechnology Advances, 25, 294-306. http://dx.doi.org/10.1016/j.biotechadv.2007.02.001

[2] Meng, X., Yang, J., Xu, X., Zhang, L., Nie, Q. and Xian, M. (2009) Biodesel Production from Oleaginous Microorganisms. Renewable Energy, 34, 1-5.

[3] Gouveia, L. and Oliveira, A.C. (2009) Microalgae as a raw Material for Biofuels Production. Journal of Industrial Microbiology \& Biotechnology, 36, 269-274. http://dx.doi.org/10.1007/s10295-008-0495-6

[4] Mata, T.M., Martins, A.A. and Caetano, N.S. (2010) Microalgae for Biodiesel Production and Other Applications: A Review. Renewable and Sustainable Energy Reviews, 14, 217-232. http://dx.doi.org/10.1016/j.rser.2009.07.020

[5] Hu, Q., Sommerfeld, M., Jarvis, E., Ghirardi, M., Posewitz, M., Seibert, M. and Darzins A. (2008) Microalgal Triacylglycerols as Feedstocks for Biofuels Production: Perspectives and Advances. The Plant Journal, 54, 621-39. http://dx.doi.org/10.1111/j.1365-313X.2008.03492.x

[6] Schenk, P.M., Thomas-Hall, S.R., Stephens, E., Marx, U.C., Mussgnug, J.H., Posten C., kruse, O. and Hankamer, B. (2008) Second Generation Biofuels: High-Efficiency Microalgae for Biodiesel Production. Bioenergy Research, 1, $20-$ 43. http://dx.doi.org/10.1007/s12155-008-9008-8

[7] Chen, F. (1996) High Cell Density Culture of Microalgae in Heterotrophic Growth. Tibtech November, 14, 421-426.

[8] Chen, G.Q. and Chen, F. (2006) Growing Phototrophic Cell without Light. Biotechnology Letters, 28, 607-616. http://dx.doi.org/10.1007/s10529-006-0025-4

[9] Wu, Z.Y. and Shi, X.M. (2006) Optimization for High-Density Cultivation of Heterotrophic Chlorella Based on a Hybrid Neural Network Model. Letter in Applied Microbiology, 44, 13-18. http://dx.doi.org/10.1111/j.1472-765X.2006.02038.X

[10] Liu, J., Huang, J.C., Fan, K.W., Jiang, Y., Zhong, Y.J., Sun, Z. and Chen, F. (2010) Production Potential of Chlorella zofinginesis as A Feedstock for Biodisel. Bioresoure Technology, 101, 8658-8663. http://dx.doi.org/10.1016/j.biortech.2010.05.082

[11] Griffiths, M.J. and Harrison, S.T.L. (2009) Lipid Productivity as a Key Characterisic for Choosing Algal Species for Biodiesel Production. Journal of Applied Physiology, 21, 493-507. http://dx.doi.org/10.1007/s10811-008-9392-7

[12] Miao, X. and Wu, Q. (2004) High Yield Bio-Oil Production from Fast Pyrolysis Bymetabolic Controlling of Chlorella protothecoides. Journal of Biotechnology, 110, 85-93. http://dx.doi.org/10.1016/j.jbiotec.2004.01.013

[13] Rodolfi, L., Zittelli, G.C., Bassi, N., Padovani, G., Biondi, N., Bonini, G. and Tredici, M.R. (2008) Microalgae for Oil: Strain Selection, Induction of Lipid Synthesis and Outdoor Mass Cultivation in a Low-Cost Photobioreactor. Biotech- 
nology and Bioengineering, 102, 100-112. http://dx.doi.org/10.1002/bit.22033

[14] Sheehan, J., Dunahay, T., Benemann, J. and Roessler, P. (1998)A Look Back at the US Department of Energy's Aquatic Species Program: Biodiesel from Algae. Close-Out Report. National Renewable Energy Lab, Department of Energy, Golden, Report Number NREL/TP-580-24190.

[15] Rippka, R., Deruelles, J., Waterbury J., Herdman M. and Stanier R. (1979) Generic Assignments, Strain Histories and Properties of Pure Cultures of Cyanobacteria. Journal of General Microbiology, 111, 1-61. http://dx.doi.org/10.1099/00221287-111-1-1

[16] Yokoyamam, R. and Honda, D. (2007)Taxonomic Rearrangement of the Genus Schizochytrium sensu lato Based on Morphology, Chemotaxonomic Characteristics, and 18S rRNA Gene Phylogeny (Thraustchytriceae, Labyrinthulomycetes): Emendation for Schizochytrium and Erection of Aurantiochytrium and Ologichytrum gen. nov. Mycoscience, 48, 199-211. http://dx.doi.org/10.1007/S10267-006-0362-0

[17] Bligh, E.G. and Dyer, W.J. (1959) A rapid Method for Total Lipid Extraction and Purfication. Canadian Journal of Biochemistry and Physiology, 37, 911-917. http://dx.doi.org/10.1139/059-099

[18] Rozés, N., Garbay, S., Denayrolles, M. and Lonvaud-Funel, A. (1993) A Rapid Method for the Determination of Bacterial Fatty Acid Composition. Letters in Applied Microbiology, 17, 126-131. http://dx.doi.org/10.1111/j.1472-765X.1993.tb01440.x

[19] Becker (1994) Measurement of Algal Growth. In: Microalgae Biotechnology\& Microbiology, Cambridge University Press, Cambridge, 56-62.

[20] Wu, Q.Y., Yin, S., Sheng, G.Y. and Fu, J.M. (1992) A Comparative Study of Gases Generated from Simulant Thermal Degradation of Autotrophic and Heterotrophic Chlorella. Progress in Natural Science (in Chinese), 3, 435-440.

[21] Miller, G.L. (1959) Use of Dinitrosalicylic Acid Reagent for Determination of Reducing Sugar. Analytical Chemistry, 31, 426-429. http://dx.doi.org/10.1021/ac60147a030

[22] Ohlrogge, J. and Browse, G. (1995) Lipid Biosynthesis. The Plant Cell, 7, 957-970. http://dx.doi.org/10.1105/tpc.7.7.957

[23] Borowitzka, M.A. and Borowitzka, L.J. (1988) Microalgal Biotechnology. Cambridge University Press, Cambridge.

[24] Konthe, G. (2009) Improving Biodiesel Fuel Properties by Modifying Fatty Ester Composition. Energy \& Environmental Science, 2, 759-766. http://dx.doi.org/10.1039/b903941d

[25] Konthe, G. (2008) “Designer” Biodiesel: Optimizing Fatty Ester Composition to Improve Fuel Properties. Energy \& Fuels, 22, 1358-1364. http://dx.doi.org/10.1021/ef700639e

[26] Sohi, C. (2010) Microalgae Biodiesel as a Substitute for Jet Fuel. California State University, Sacramento.

[27] Chen, F. and Johns, M.R. (1991) Effect of C/N Ratio and Aeration on the Fatty Acid Composition of Heterotrophic Chlorella sorokiniana. Journal of Applied Phycology, 3, 203-209. http://dx.doi.org/10.1007/BF00003578

[28] Damian, I.M.C., Popovich, C.A., Constenla, D. and Leonardi, P.I. (2010) Lipid Analysis in Haematococcus pluvialis to Assess Its Potential Use as a Biodisel Feedstock. Bioresoure Technology, 101, 3801-3807.

[29] Kong, Q.X., Li, L., Martinez, B., Chen, P. and Ruan, R. (2010) Culture of Microalgae Chlamydomonas reinhardtii in Wastewater for Biomass Feedstock Production. Applied Biochemistry and Biotechnology, 160, 9-18. http://dx.doi.org/10.1007/s12010-009-8670-4

[30] Morowvat, M.H., Rasoul-Amini, S. and Ghasemi, Y. (2010)Chlamydomona as a "New” Organism for Biodiesel Production. Bioresoure Technology, 101, 2059-2062. http://dx.doi.org/10.1016/j.biortech.2009.11.032

[31] Rao, A.R., Dayananda, C., Sarada, R., Shamala, T.R. and Ravishankar, G.A. (2007) Effect of Salinity on Growth of Green Alga Botryococcusbraunii and Its Constituents. Bioresource Technology, 98, 560-564. http://dx.doi.org/10.1016/j.biortech.2006.02.007

[32] Maeda, Y., Sugiyama, H., Sato, S. and Tanaka, T. (2009) Characterization of Marine Microalga, Scenedesmus sp. Strain JPCC GA0024 toward Biofuel Production. Biotechnology Letters, 31, 1367-1372. http://dx.doi.org/10.1007/s10529-009-0029-y

[33] Cao, J., Yuan, H.L., Li, B.Z. and Yang, J.S. (2013) Significance Evaluation of the Effects of Environmental Factors on the Lipid Accumulation of Chlorella minutissima UTEX 2341 under Low-Nutrition Heterotrophic Condition. Bioresource Technology. http://dx.doi.org/10.1016/j.biortech.2013.10.084 